\title{
Herbicides and its role in Induction of Oxidative
}

\section{Stress- A Review}

\author{
Gurvinder Kaur
}

College of Animal Biotechnology, Guru Angad Dev Veterinary and Animal Sciences University, Ludhiana, 141004 India Kaur.gurvinder2016@gmail.com

\begin{abstract}
Herbicides are one of the most extensively used classes of pesticides, which provide a convenient, economical and effective way to manage weeds. However the regular and endless use of herbicides affects environmental, ecological, and human health. Herbicides can be classified in several ways but the most common method of classifying herbicides is by their mode of action and target site. Several stress events gene rated upon the herbicide action can lead to oxidative dis-balance in various non-target species. Most of the perturbations caused by herbicide treatment in plants are related to ROS generation. Overproduction and accumulation of ROS result in metabolic disorders and can lead to oxidative destruction of the cell. This review provides a brief overview of alterations in enzymatic antioxidants on exposure to different herbicides in various experimental models.
\end{abstract}

Keywords-Herbicides, Antioxidants, Oxidative stress.

\section{INTRODUCTION}

Pesticide is defined as any substance or a mixture of substances (chemical or biological) that deters, incapacitates or kills pests. Pesticides are generally used to eliminate or hinder the growth of a variety of agricultural pests that can damage crops, livestock and reduce farm productivity. There are many different types of pesticides, each is meant to be effective against specific pests and minimize the losses. Besides their widespread use and as a friend to farmer, these agricultural pesticides create an imbalance in the ecosystem and add to that most of the pesticides are broad spectrum, resulting in affecting other organisms including humans directly or indirectly. According to Kumar et al. 2013 extensive use of pesticides has a harmful impact on biological diversity resulting in biodiversity loss. Pesticide use raises a number of environmental concerns. A report (Miller GT 2004) says that over $98 \%$ of sprayed insecticides and $95 \%$ of herbicides reach a destination other than their target species, including non-target species, air, water and soil. A recent study (Fan 2017) found nearly 3000 children were poisoned by pesticides in eastern China's Zhejiang province between 2006 and 2015, with most cases occurring during the farming season. As the substituent of chemical pesticides (Jafarbeigi et al. 2014), bio-pesticide use is quickly increasing and they are expected to become the predominant pesticides in the future. Herbicides are one class of pesticides used to prevent or eliminate weeds. Herbicides can be broadly classified into 2 types, Contact and Systemic herbicides. Contact herbicides kill only, whereas the systemic herbicides are absorbed by the roots or foliage and trans-located throughout the plant. Herbicides ensure a convenient, economical, and effective way to help manage weeds. Weeds reduce the yield and originality of valuable commercial crops, ornamentals, forestry, and turf grass. Weeds also damage crops and other landscapes in a secondary way, serving as hosts for a variety of insects and fungi. However, the regular and endless use of herbicide carries risks that include environmental, ecological, and human health effects. It is important to understand both the benefits and disadvantages associated with chemical weed control before selecting the appropriate control.

Herbicides can be classified several ways, including by weed control spectrum, labelled crop usage, chemical families, mode of action, application timing/ method, and others. Many factors determine when, where, and how a particular herbicide can be used most effectively. A common method of classifying herbicides is by their mode of action and target site. Herbicide mode of Action is related to herbicide treatment and is a step by step process. Each herbicide mode of action (MOA) has a specific target site (TS) which is referred to as a mechanism of Action (MA). This is usually an enzyme/protein which is inhibited by the herbicide at a molecular level. The MOA for some herbicides induces the generation of ROS in plants as secondary effects after the specific TS are sufficiently inhibited. Caverzan et al. 2019 reports that after the active herbicide reach and inhibit the TS, a series of stress events are initiated by the signalling 
of plant defense systems against perturbations. In this case, the oxidative stress generated is responsible for an important part of cellular and tissue damage. From total known groups of herbicides classified according to the mode of action, $71 \%$ of them are known to cause ROS overproduction after their target site inhibition.

Globally, (Heap 2014) herbicides are the predominant method for controlling weeds in modern crop production, contributing to protecting the crop yield and economic profit. Cobb AH and Reade PHR et al. 2010 reports that despite the inherent selectivity mechanisms that facilitate crop production, herbicides can cause some phytotoxicity to crop plants and cause reductions in leaf area index (LAI), shoot dry weight (SDW), plant height, and alterations in plant metabolism by generating ROS. Most of the perturbations caused by herbicide treatment in plants are related to ROS generation. Overproduction and accumulation of ROS results in metabolic disorders and can lead to the oxidative destruction of the cell. They also pointed that the response time for oxidative stress occurrence and visible plant damage varies with the herbicide mode of action, type of herbicide and formulation, plant species, development stage, and environmental conditions. For example, paraquat (photosynthes is inhibitor-PSI) damage could be observed from 2 hours after treatment under light conditions, and susceptible plants die from 3 to 7 days after. On the other hand, the first visible plant symptoms fromglyphosate and plant death for susceptible species may occur around 5 days and 7 to 15 days, respectively. Herbicide Resistance Action Committee (HRAC 2019) has classified some of the herbicides which show ROS production at some phase of their mechanism of action. Some of the herbicides kill plants by direct ROS production while others cause ROS production as a secondary effect. Table 1 gives the list of Herbicide chemical family which directly produce ROS upon action and which produce ROS as a secondary effect.

\section{Global Herbicide usage}

Herbicides are used to destroy weeds and are still the largest product type accounting for $47.6 \%$ of global pesticide sales (Vats 2014) followed by insecticide $29.4 \%$, fungicide $17.5 \%$ and others $(5.5 \%)$. According to Wenjun Zhang 2018, Global insecticides, herbicides, and fungicides \& bactericides use and cost / benefit declined with time since 2007. Conversely, the cost/benefit of triazoles/diazoles and the use of triazoles/diazoles, plant growth regulators, and amides, have significantly increased since 2007. In his survey, he concluded that in case of herbicides the use of amides and other herbicides have continually increased since 1990. The use of triazines, urea derivates, uracil and bipiridils increased with time during 1990 and 2007, but bipiridils use declined since 2007. According to the Linear regressions and projection of global pesticide use made by him it shows that Tones of active ingredients of herbicides have been increased till 2014. Ascending trend was seen in herbicides Triazines, Amides, urea derivatives, Bipridils, uracil and other herbicides. Statistically significant regression was seen in amides and other herbicides during 1990-2007 and during 2007-2014. In the survey conducted in 2014, it was reported that amides is the most used herbicides, followed by phenoxy hormone products, bipridils, triazines, urea derivatives. In 2016, the registrations of the three major types of pesticides accounted for $92.4 \%$ of the newly registered in the year, and the registrations of fungicides \& bactericides and herbicides exceeded that of pesticides, of which 774 were fungicides \& bactericides, 749 were herbicides and 560 were insecticides. Fan 2017 reported that only $30-40 \%$ of pesticides directly act on target crops and pests. Therefore, if pesticides fully function without any waste, by using various accurate tools and methods, $\sim 0.18$ to $\sim 0.24 \mathrm{~g}$ pesticide use (total) $/ \mathrm{kg}$ crop production, or $\sim 0.81$ to $\sim 1.08 \mathrm{~kg} / \mathrm{ha}$ of pesticide use (total) are the most ideal indices for pesticide use (total) at the present crop yield levels and production conditions. From their report, the estimated cost / benefit ( $g$ herbicides use / $\mathrm{kg}$ crop production) for Brazil, Canada, France, Germany, Japan, Mexico, UK, and USA during $2017-2020$ are $\sim 1.05, \sim 0.80, \sim 0.30, \sim 0.25, \sim 0.41, \sim 0.35, \sim 0.20$, and $\sim 0.45$, respectively, and the estimated herbicides use during this period are $\sim 3.4, \sim 2.1, \sim 2.1, \sim 2.1, \sim 4.1, \sim 1.6$, $\sim 1.6$, and $\sim 2.0 \mathrm{~kg} / \mathrm{ha}$, respectively.

\section{EFFECT OF HERBICIDES ON NON TARGET SPECIES AND ENVIRONMENT}

Herbicides are the most widely used class of pesticides, accounting for more than $60 \%$ of all pesticides applied in agriculture (Kniss AR 2017). An increasing number of epidemiological studies have suggested that current levels of exposure are associated with risks to human health, including chronic diseases, cancers, neurological deficits, birth defects, and reproductive disorders. Pesticides can produce adverse physiological or biological effects, with a variety of biochemical changes at the molecular, cellular, or tissue level. McCauley LA et al. 2006 states that the most common biomarkers used to assess pesticide effects are related to DNA and RNA damage, modulation of gene expression, and oxidative stress. Study by Benbrook CM, 2016 reports that the widespread application of glyphosate to crops has spurred the spread of tolerant and resistant weeds in the US, and 
worldwide, which in turn has created the need for more frequent applications at higher concentrations. In 2015, IARC classified glyphosate as a "probable human carcinogen" (IARC 2016), although in the same year EFSA (European Food and Safety Authority) declared that "glyphosate is unlikely to pose a carcinogenic hazard to humans" (EFSA 2016) based on typical, expected exposures to the general public. Among the general population, the information available (Curwin BD et al. 2007; Kruger M et al. 2014), suggests that mean levels of glyphosate in urine samples are generally below $4 \mu \mathrm{g} / \mathrm{L}$. However, Acc to Varona M et al. 2009 in areas where aerial spraying is administered, mean urinary concentrations in the population above the LOD can reach as high as $7.6 \mu \mathrm{g} / \mathrm{L}$. Studies like Kongtip P et al. 2017 shows that even expectant mothers, a population that typically avoids excess chemical exposure, can have serum glyphosate levels as high as $189 \mu \mathrm{g} / \mathrm{L}$. Curwin BD et al. 2005 detected glyphosate in the dust of both farming and non-farming households, indicating that this exposure extends beyond occupational settings. According to the EPA (Environmental Protection Agency) assessment the residues in food ranged from $100 \mu \mathrm{g} / \mathrm{L}$ in vegetables like tomatoes and pepper to $200,000 \mu \mathrm{g} / \mathrm{L}$ in peppermint and peppermint oils.

Some herbicides may have lethal or sublethal, direct and/or indirect effects (Moffett JO et al. 1972), on pollinators, whereas others do not appear to cause any effects. Herbicide such as paraquat is highly toxic to honeybees when applied topically Whereas when fed to honey bee colonies (Morton HL et al. 1972), the herbicides 2,4-D and 2,4-trichlorophenoxyacetic acid do not appear toxic to adult bees but can negatively influence brood development. Study done on microalgal species (Prado et al. 2009) also reports adverse effects caused by paraquat on common fresh water green microalga. They have reported that paraquat induces alterations in the elemental and biochemical composition of non-target microalgal species. Despite the limited use, herbicide dicamba and 2,4-D are often responsible for injury to non target plants but effects of these herbicides on insect communities are poorly understood. Study by Bohenblust EW et al. 2016 reports that sublethal doses of dicamba approximating particle drift events can delay, reduce, or prevent flowering of plant species found in agricultural landscapes and lead to reduced visitation by pollinators. Sublethal doses of dicamba $(0.1-1 \%$ of the field application rate) caused delays and reductions in flowering of susceptible and agro ecologically significant plant species.

Phenoxy acid (PA) herbicides often persist in the soil environment under natural conditions leading to leaching (Baelum $\mathrm{J}$ et al. 2012), in groundwater reservoirs. The herbicides reach the groundwater even though PA degraders are commonly found in natural soil environments. Silveyra GR et al. 2018 hypothesized that atrazine (a pre and post emergent weed controller) reduces the ovarian growth of Procambarus clarkii (female red swamp crayfish), presumably by interfering with the hormonal regulation of gonadal growth in females. The results indicate a clear inhibition of ovarian growth in crayfish exposed to atrazine, especially at the highest concentration used. Supporting the above results, Alvarez et al. 2015 reported a delay in ovarian rematuration of $\mathrm{N}$. granulata with atrazine exposure, during the reproductive period. They have shown that atrazine was able to inhibit vitellogenin production in Procambarus clarkii females, via inhibition of its expression in both ovary and hepatopancreas, therefore reducing ovarian growth. On the other hand, atrazine produced higher titters of estradiol, which could have counteracted some of the inhibiting effects mentioned above, particularly in the hepatopancreas. Wetzel LT et al. 1994 also reported Atrazine as a cause of formation of mammary gland tumours in female Sprague-Dawley rats, which implies that it may be carcinogenic. Remera, a French national birth defect agency, recently identified clusters of children born with malformed limbs in 3 rural regions in france. When they looked into the causes, they proposed that the limb malformations could result from exposure to environmental pollutants and toxins, which include pesticides \& herbicides that are used in nearby farms (report by French national registry, March 2019). A study (Helen et al. 2018) on black grass reports that herbicides can no longer control the weeds that threaten the crop productivity and food security in UK because plants have evolved resistance and they found that the extent of herbicide resistance was primarily dictated by the historical intensity of number of herbicide applications.

\section{HERBICIDES AND INDUCTION OF OXIDATIVE STRESS}

In crops field, many herbicides are used to control weed, however, these toxicants can remain in the soil for long periods and can contaminate rivers and subterranean waters. Thus, these chemicals can promote several ecotoxicological and environmental effects (Carla A et al. 2018), as they elicit alterations on antioxidant system in non-target organisms, as on sensitive plants. Herbicides like fomesafen and sulfentrazone are inhibitors of protoporphyrinogen oxidase (PROTOX) system. Protox inhibition leads to generation of singlet oxygen through the action of protoporphyrinogen oxidase enzyme. This $\mathrm{O}_{2}$ in 
the singlet state is responsible for peroxidation of lipids in cell membranes. As a cascade effect (Oliveira et al. 2002), free radicals are formed resulting in the degradation of lipids and proteins, leading to loss of chlorophyll, carotenoids and disruption of cell membranes. Various abiotic stresses like extreme temperatures, high winds, and droughts can lead to the overproduction of Reactive Oxygen Species (ROS) in plants, which are reactive and toxic causing damage to proteins, lipids, carbohydrates and DNA, which ultimately results in oxidative stress (Gill and Tuteja 2010). Among the main enzymatic antioxidant defenses, are superoxide dismutase (SOD), ascorbate peroxidase (APX), guaiacol peroxidase (GPX) and catalases (CAT), which promote the control of ROS levels. Thus, the knowledge of role of SOD, APX, CAT and peroxidases enzymes defines the status of the antioxidant system, which is very important in the reduction of the levels of ROS in the cells (Apel and Hirt 2004), avoiding the oxidative stress promotion. The increase in SOD activity may be one of the possible reasons for an increased lipid peroxidation in plants treated with oxyfluorfen, while, as the activity of SOD increases, hydrogen peroxide levels also increase. SOD, considered the first line of defense against the damage caused by ROS (Wang et al. 2012), catalyzes the conversion of superoxide anion $\left(\mathrm{O}_{2}-*\right)$ into $\mathrm{H}_{2} \mathrm{O}_{2}$ and $\mathrm{O}_{2}$ in chloroplasts, mitochondria, cytoplasm and peroxis omes.

The herbicides pendimethalin and oxyfluorfen causes lower net photosynthesis, increase substomatic $\mathrm{CO}_{2}$, a lower water use efficiency and carboxylation. Langaro A.C. et al. 2017 reports that even selective herbicides registered for weed control in rice crops cause phytotoxicity, reduce height and alter the metabolism of plants, generating reactive oxygen species, activating enzymatic and non-enzymatic defense mechanisms and results in the degradation of photosynthetic pigments and in reduced protein content. Table 2 gives a brief overview of changes in antioxidant parameters in various experimental models after exposure to different herbicides. Generally, dysfunction in the antioxidant system results in establishment of oxidative stress, which could progress to lipid peroxidation.

Study by Carla A et al. 2018 found that Fomesafen causes a significant decrease in CAT activity in $V$. sativa. $R$. sativus and L. albus, related to the herbicide concentration increase. On other hand, CAT activity increased significantly for A. sativa, with the increase of Fomesafen concentration. Herbicide sulfentrazone causes a significant decrease in GPX activity for A. Sativa (37\%), R. sativus (89\%), L. albus (95\%), and V. Sativa. This study revealed the effect of herbicide exposure in the promotion of oxidative stress and response of antioxidant defense mechanism in species used as green manure. Decrease in the CAT enzyme activity, is directly related to the increase in the lipid peroxidation. Several studies like (Agostinetto et al. 2016) demonstrated the effects of herbicides bentazon, clodinafop, iodosulfuron, metribuzin, metsulfuron and 2,4-D under Rhapanus sativus which shows an increase in CAT activity. MDA accumulation in absolute values was observed in the treatments with metsulfuron and 2,4-D. Increasing fomesafen and sulfentrazone concentration $(\geq 0.25 \mathrm{~kg}$ ha- 1 and $0.6 \mathrm{~kg}$ ha1) induced increase in reactive oxygen species levels in the plant which could weaken the antioxidant defense system.

Atrazine, a widely use herbicide, has been classified as a potential endocrine disruptor (Graymore M et al. 2001), especially for freshwater species. This report says that in waters adjacent to treated fields, as well as in groundwater, atrazine concentrations were as high as 1 $\mathrm{mg} / \mathrm{L}$. Although this herbicide is not commonly absorbed in sediments (Jablonowski ND et al. 2011), the fraction associated to this substrate can be very significant. It is seen that mixture of atrazine with other pesticides such as glyphosate caused both lipid peroxidation and DNA damage (Santos and Martinez 2014) in several tissues of clams. According to silverya GR et al. 2018 a metabolic effort (evidenced by the augmented lactate production), together with the increase of glutathione levels were observed, evidencing a clearly stressful effect of the herbicide. Thus, the role of antioxidant enzymes in stress situations is to control the accumulation of ROS (Sharma et al. 2012), limiting oxidative damage. Lipid peroxidation is one of the most investigated consequences of the actions of ROS on membrane structures (Amri and Shahsavar 2010), being one of the first responses to damage induced by stress in plant tissues. As for atrazine effects on antioxidant enzyme activities, sub-chronic exposure to an environmentally relevant concentration of atrazine $(0.3 \mu \mathrm{g}$ L-1) (Chromcova L et al. 2013), caused an increase in the activity of CAT, GPx, GST, and SOD in common carp embryos and larvae, whereas sub-chronic exposure to environmentally relevant concentration of atrazine-2hydroxy $(0.66 \mu \mathrm{g} \mathrm{L}-1)$ did not affect their activities. In adult carp, Xing $\mathrm{H}$ et al. 2012 reported that a 40-day exposure to atrazine in concentrations above $42.8 \mu \mathrm{g} \mathrm{L}-1$ resulted in a decrease in CAT, GPx, and SOD activities. In adult zebrafish (Danio rerio), a 28-day exposure to low atrazine concentrations, including the environmentally relevant $0.3 \mu \mathrm{g}$ L-1 caused a decrease in CAT (Blahova $\mathrm{J}$ et al. 2013), but acc to Zhu LS et al. 2011 exposure to higher concentrations of atrazine $(>100 \mu \mathrm{g}$ L-1) for 14 or 21 days resulted in an increase in CAT and SOD activities 
in the liver homogenate. Two studies in drosophilids (Torres C et al.1992; Marcus SR et al. 2016) observed developmental and genotoxic effects, which prompted Figuera et al. 2017 to expose the embryos (newly fertilised eggs) of the fruit fly Drosophila melanogaster to atrazine concentrations ranging between 10 and $100 \mu \mathrm{mol}$ L-1 through diet until they developed into adult flies. Larvae showed no changes in ROS levels, the adult flies did, so they concluded that redox imbalance must have been related to changes in metabolism after metamorphosis. In another study (Williams JR 2016), honeybees in a laboratory were exposed to atrazine concentrations ranging from 0.1 to $10 \mu \mathrm{g} \mathrm{L}-1$ for 24 hours, whereas hives in the field were treated with $10 \mu \mathrm{g} \mathrm{L}-1$ of atrazine a day for 28 days. GPx and GST activities dropped, whereas MDA levels increased in both the laboratory and hive honeybees. In a number of studies (Singh M et al. 2010, 2011; Shirisha $\mathrm{K}$ and Mastan M 2013) sub-chronic exposure to $300 \mathrm{mg}$ $\mathrm{kg}-1$ of atrazine increased the activities of CAT, SOD, GPX, and GST and decreased GSH levels in blood and liver. At doses from $25-200 \mathrm{mg} / \mathrm{kg}$ (Abarikwu SO et al. 2010) exposure to atrazine lowered CAT activity in rat testis.

According to study done by Langaro A.C.et al. 2017 on rice plants they found that exposure of preemergent herbicides oxyfluorfen and oxadiazon resulted in increased activity of superoxide dismutase \& catalase enzymes compared to control. When evaluated ascorbate peroxidase activity, there was a higher enzyme activity in plants treated with oxadiazon and pendimethalin. In order to keep ROS under control plants balance ROS \& their antioxidant system. Thus, an efficient combination of SOD, CAT and APX would minimize the effects of oxidative stress, (Damanik et al. 2012) playing an important role in the regulation of ROS.

Terbuthylazine (N2-tert-butyl-6-chloro-N4-ethyl1,3,5- triazine-2,4-diamine) has become the key triazine in Europe (Sass JB. and Colangelo A. 2006) in the last two decades. It is also used as an aquatic herbicide (WHO 2018) to control submerged and free floating weeds and algae in water courses, reservoirs, and fish ponds. According to the European Food Safety Agency (EFSA), it poses a high risk to non-target plants in the off field areas. EFSA has also warned about high toxicity of both terbuthylazine and its metabolite desethylterbuthylazine to aquatic organisms. This herbicide persists in the environment and has a tendency to easily move from treated soils to water compartments (Calderon MJ et al. 2016; Stipicevic S et al. 2017) through runoffs and leaching. Very little is known about effects of terbuthylazine on oxidative stress parameters and antioxidant defence in mammals. Furthermore, Acc to EEA 2011, s-triazines have been identified as substances hazardous to the aquatic environment and have been included in the EU Priority Pollutants List. It is evident that environmentally relevant concentrations of terbuthylazine do not generally affect the oxidant/ antioxidant balance, but its metabolites do turned. In other environmentally relevant organisms such as drosophila and honeybees (Tanja Z S et al. 2018), atrazine turned out to be more of a concern because of evident lipid peroxidation and antioxidant depletion.

The mechanism of the toxic action of phenoxy herbicides, including 2,4-D and its metabolites (Bukowska B et al. 2008; Busi R et al. 2018), toward weeds is associated with the generation of ROS and lipid peroxidation. 2,4-D presence led to a decrease in fungal catalase activity, (given in Table 2) associated with a higher amount of thiobarbituric acid-reactive substances (TBARS). The higher TBARS level found in the $U$. isabellina biomass from 2,4-D cultures confirmed the induction of oxidative stress. This phenomenon results from a disturbance between the generation of ROS and their removal by the antioxidant defense system. According to Busi R et al. 2018 susceptible plants treated with 2,4-D, production of $\mathrm{H}_{2} \mathrm{O}_{2}$ and reactive oxygen species leads to plant death. High levels of MDA were also observed in Escherichia coli strains exposed to the herbicide 2,4-dichlorophenoxyacetic acid. According to Balague et al. 2001 bacterial cells modify their membrane lipid molecules to avoid the toxic effects of the herbicide. This study demonstrated that bacteria exposed to 2,4-D may reduce membrane fluidity to withstand chemical injury; because of lipid-protein interactions, the transport processes of molecules may be diminished. Study (Duchnowicz P and koter M 2003) has shown that 2,4-D caused lipid peroxidation as well as the increase in membrane fluidity at the 16 carbon atom of fatty acids and also hemolysis in human erythrocytes. Suwalsky M et al. 1996 has also shown that 2,4-D disturbs phospholipid bilayer integrity which is essential for the proper condition of cell membrane. The authors postulated that morphological transformation of erythrocytes might be the result of specific oxidative transformation of membrane skeleton. 2,4-D leads to the formation of methemoglobin (Bukowska B et al. 1998) which is unable to transport oxygen. This conversion is associated with superoxide anion production (Mishra HP and Fridovich K 1972) and thereby with the formation of products such as hydrogen peroxide or hydroxyl radicals that may be derived from superoxide anion itself. 


\section{CONCLUSION}

Different herbicides react differently on various non target species. These are very effective in managing the growth of weeds, known to cause lower growth and productivity in plants, but on the other hand these herbicides are known to cause ill effects and severe perturbations in non-target organisms. One mechanism which leads to environmental, ecological and human health risks is ROS imbalance. Antioxidant alterations generated in response to herbicide mode of action is responsible for an important part of cellular and tissue damage. In this review, I have tried to summarise the oxidative levels or antioxidant alterations caused by different herbicides in several non target species. In most of the studies it is noted that overdose or erratic application of herbicides leads to oxidative damage and alterations in antioxidant parameters.

\section{REFERENCES}

[1] Abarikwu SO, Adesiy an AC, Oyeloja TO, Oyeyemi MO, Farombi EO. 2010. Changes in sperm characteristics and induction of oxidative stress in the testis and epididymis of experimental rats by a herbicide, atrazine. Arch Environ Con Tox 58: 874-82.

[2] Agostinetto D, Perboni LT, Langaro AC, Gomes J, Fraga ds AND Franco JJ. 2016. Changes in photosynthesis and oxidative stress in wheat plants submmited to herbicides application. Planta Daninha 34: 1-9.

[3] Alvarez NB, Avigliano L, Mac Loughlin C, Rodriguez EM. 2015. The adverse effect of the herbicide atrazine on the reproduction in the intertidal varunid crab Neohelice granulata (Dana, 1851). Reg. Stud. Mar. Sci. 1: 1-6.

[4] Amri E and Shahsavar A. 2010. Response of lime seedlings (Citrus aurantifolia L.) to exogenous spermidine treatments under drought stress. Aust. J. Basic \& Appl. Sci. 4(9): 4483-89.

[5] Langaro AC, Agostinetto D, Ruchel Q, Garcia JR and Perboni LT. 2017. Oxidative stress caused by the use of preemergent herbicides in rice Crops Rev. Cienc. Agron. 48(2): 358-64.

[6] Apel K and Hirt H. 2004. Reactive Oxygen Species: Metabolism, Oxidative Stress, and Signal Transduction. Annu Rev Plant Biol 55: 373-99.

[7] Baelum J, Prestat E, David MM, Strobel BW, Jacobsen CS. 2012. Modeling of phenoxy acid herbicide mineralization and growth of microbial degraders in 15 soils monitored by quantitative real-time PCR of the functional tfdA gene. Appl Environ Microbiol 78: 5305-12.

[8] Balague C, Sturtz N, Duffard R, Evangelista de Duffard AM. 2001. Effect of 2,4-D herbicide on Escherichia coli growth, chemical, composition and cellular envelope. Environ Toxicol 16(1): 43-53.

[9] Benbrook CM. 2016. Trends in gly phosate herbicide use in the United States and globally. Environ Sci Eur. 28(1): 3.
[10] Bernat P, Nykiel-Szymanska J, Stolarek P, Soaba M, Szewczyk R, Roazalska S. 2018. 2,4dichlorophenoxyacetic acid-induced oxidative stress: Metabolome and membrane modificationsnin Umbelopsis isabellina, a herbicide degrader. Plos one 13(6): e0199677.

[11] Blahova J, Plhalova L, Hostovsky M, Divisova L, Dobsikova R, Mikulikova I, Stepanova S, Svobodova Z. 2013.Oxidative stress responses in zebrafish Danio rerio after subchronic exposure to atrazine. Food Chem Toxicol 61: 82-5.

[12] Bohnenblust EW, Anthony D. Vaudo, J. Franklin Egan, David A. Mortensen, and John F. Tooker. 2016. Effects of the herbicide Dicamba on nontarget plants and pollinator visitation Environ Toxicol Chem 35(1): 144-51.

[13] Bukowska B, Reszka E, Duda W. 1998. Influence of phenoxyherbicides and their metabolities on the from of oxy- and deoxyhemoglobin of vertebrates. Biochem. Mol. Biol. Int. 45-47.

[14] Bukowska B, Rychlik B, Krokosz A, Michaowicz J. 2008. Phenoxyherbicides induce production of free radicals in human erythrocytes: oxidation of dichlorodihydrofluorescine and dihydrorhodamine 123 by 2,4- D-Na and MCPA-Na. Food Chem. Toxicol. 46: 35967.

[15] Busi R, Goggin DE, Heap IM, Horak MJ, Jugulam M, Masters RA. 2018. Weed resistance to synthetic auxin herbicides. Pest. Manag. Sci. https://doi.org/10.1002/ps.4823 PMID: 29235732.

[16] Calderon MJ, De Luna E, Gomez JA, Hermosin MC. 2016. Herbicide monitoring in soil, runoff waters and sediments in an olive orchard. Sci Total Environ (569-570): 416-22.

[17] Carla A , Eduarda C, Jessica R. Sofiatti, Cesar T. Forte, Fábio . Winter, Cinthia M. Holz, Rosilene R. Kaizer and Leandro Galon. 2018. Effect of herbicides in the oxidative stress in crop winter species An. Acad. Bras. Cienc.90(2): 1533-42.

[18] Caverzan A, Piasecki C, Chavarria G, Stewart C.N Jr, Vargas L.2019. Defenses against ROS in Crops and Weeds: The Effects of Interference and Herbicides. Int. J. Mol. Sci. 20: 1086.

[19] Chromcova L, Blahova J, Plhalova L, Zivna D, Stepanova S, Praskova E, Zelníckova L, Skoric M, Svobodova Z. 2013. The effects of atrazine exposure on early life stages of common carp (Cyprinus carpio). Neuroendocrinol Lett 34(Supp12): 95-101.

[20] Cobb AH and Reade PHR. 2010. Herbicides and Plant Physiology, 2nd ed.; JohnWiley \& Sons: New York, NY, USA, 286p.

[21] Curwin BD, Hein MJ, Sanderson WT, Nishioka MG, Reynolds SJ, Ward EM, Alavanja MC. 2005. Pesticide contamination inside farm and nonfarm homes. J Occup Environ Hyg. 2(7): 357-67.

[22] Curwin BD, Hein MJ, Sanderson WT, Striley C, Heederik D, Kromhout H, Reynolds SJ, Alavanja MC. 2007a. Urinary pesticide concentrations among children, mothers and fathers living in farm and nonfarm households in Iowa. Ann Occup Hyg. 51(1): 53-65. 
[23] Damanik RI et al. 2012. Response of antioxidant systems in oxygen deprived suspension cultures of rice (Oryza sativa L.). Plant Growth Regul. 67(1): 83-92.

[24] Duchnowicz P, Koter M. 2003. Damage to the ery throcyte membrane caused by chlorophenoxy acetic herbicides. Cell. Mol. Biol. Lett. 8:25.

[25] EFSA. Glyphosate: EFSA updates toxicological profile. 2016 (Accessed 8 Mar 2018). Environmental sciences, 3(2): 101-132.

[26] EPA. Revised Glyphosate Issue Paper: Evaluation of Carcinogenic Potential. 2018. (Accessed 8 Mar 2018).

[27] European Environment Agency (EEA). 2011. Hazardous Substances in Europe's Fresh and Marine Waters. An overview. Technical report 8. Luxembourg: Publications Office of the European Union.

[28] European Food Safety Authority (EFSA). 2011. Conclusion on the peer review of the pesticide risk assessment of the active substance terbuthy lazine, [display ed 4 Juny 2018].

[29] Fan LY. 2017. China Founds Pesticide Office to Combat Pollution, Overuse. http://www.sixthtone.com/news/1000987 (Accessed Oct 12, 2017).

[30] Figueira FH, De Aguiar LM, Da Rosa CE. 2017. Embryolarval exposure to atrazine reduces viability and alters oxidative stress parameters in Drosophila melanogaster. Comp Biochem Phys C.191: 78-85.

[31] Silveyraa GR, Silveyra P, Vatnickc I, Daniel Alberto Medesania, Enrique Marcelo Rodrígueza . 2018. Effects of atrazine on vitellogenesis, steroid levels and lipid peroxidation, in female red swamp crayfish Procambarus clarkia. Aquat Toxicol 197: 136-42.

[32] Gill SS and Tuteja N. 2010. Reactive oxygen species and antioxidant machinery in abiotic stress tolerance in crop plants. Plant Phy siol Biochem 48: 909-30.

[33] Graymore M, Stagnitti F, Allinson G. 2001. Impacts of atrazine in aquatic ecosystems. Environ. Int. 26: 483-95.

[34] Heap I. 2014. Global perspective of herbicide-resistant weeds. Pest Manag. Sci. 70: 1306-15.

[35] Hicks HL, C omont D, Coutts SR, Crook L, Hull R, Norris K, Neve P, Childs DZ, Frecketon RP.2018. The factors driving evolved herbicide resistance at a national scale. Nat Ecol Evol. 2(3):529-36.

[36] HRAC (Herbicide Resistance Action Commeitee); http:// www.hracglobal.com, accessed on: 28 January 2019.

[37] IARC. IARC monographs on the evaluation of carcinogenic risks to humans,

a. volume 112 Glyphosate.

http://monographs.iarc.fr/ENG/Monographs/

vol112/mono112-10.pdf. Accessed 27 Dec 2017.

[38] Jablonowski ND, Schaffer A, Burauel P. 2011. Still present after all these years: persistence plus potential toxicity raise questions about the use of atrazine. Environ.Sci. Poll. Res. 18: 328-31.

[39] Jafarbeigi F, Samih MA, Zarabi M. 2014. Sublethal effects of some botanical and chemical insecticides on the cotton whitefly, Bemisia tabaci (Hem: Aleyrodidae). Arthropods, 3(3): 127-37.
[40] Kisby GE, Muniz JF, Scherer J, Lasarev MR, Koshy M, Kow YW, McCauley L.2009. Oxidative stress and DNA damage in agricultural workers. J Agromedicine 14: 20614.

[41] Kniss AR. 2017.Long-term trends in the intensity and relative toxicity of herbicide use. Nat Commun. 8: 14865.

[42] Kongtip P, Nankongnab N, Phupancharoensuk R, Palarach C, Sujirarat D, Sangprasert S, Sermsuk M, Sawattrakool N, Woskie SR. 2017. Gly phosate and Paraquat in maternal and fetal serums in Thai women. J Agromedicine. 22(3): 282-9.

[43] Koutnik D, Stara A, Zuskova E, Kouba A, Velisek J. 2017. The chronic effects of terbuthylazine-2-hydroxy on early life stages of marbled crayfish (Procambarus fallax F. virginalis). Pestic Biochem Phys 136: 29-33.

[44] Krucek T, Korandova M, Sery M, Frydry chova RC, Szakosova K. 2015. Effect of low doses of herbicide paraquat on antioxidant defense in Drosophila. Arch Insect Biochem Physiol. 88(4): 235-48.

[45] Kruger M, Schledorn P, Schrodl W, Hoppe H-W, Lutz W, Shehata AA. 2014.Detection of Glyphosate residues in animals and humans. J Environ Anal Toxicol. 4(2): 1-5.

[46] Kumar JIN, Bora A, Kumar RN. 2013. Toxicity analy sis of pesticides on cyanobacterial species by $16 \mathrm{~S}$ rDNA molecular characterization. Proceedings of the International Academy of Ecology and environmental sciences, 3(2): 101-32.

[47] Marcus SR and Fiumera AC. 2016. Atrazine exposure affects longevity development time and body size in Drosophila melanogaster. J Insect Physiol 91-92: 18-25.

[48] McCauley LA, Kent Anger W, Keifer M, Langley R, Robson MG, Rohlman D. 2006.Studying health outcomes in farmworker populations exposed to pesticides. Environ Health Persp 114: 953-60.

[49] Miller GT 2004. "Ch. 9. Biodiversity". Sustaining the Earth ( $6^{\text {th }}$ ed.) pacific Grove, CA: Thompson learning, Inc.pp. 211-216.

[50] Misra HP and Fridovich K. 1972. The generation of superoxide radical during the autooxidation of hemoglobin. J Biol Chem 247: 6960.

[51] Moffett JO, Morton HL, Macdonald RH. 1972. Toxicity of some herbicidal sprays to honey bees. J Econ Entomol 65: $32-36$.

[52] Oliveira TK, Carvalho GJ, Moraes RNDS. 2002. Plantas de cobertura e seus efeitos sobre o feijoeiro em plantio direto. Pesq Agropec Bras, Brasília 37: 1079-87.

[53] Paula F. Martinsa, Giselle C, Priscila L. Gratao, Manuella N. Dourado, Marcos P, Welington LA, Ricardo AA. 2011. Effects of the herbicides acetochlor and metolachlor on antioxidant enzymes in soil bacteria. Process Biochem 46: 1186-95.

[54] Plhalova L, Stepanova S, Blahova J, Praskova E, Hostovsky M, Skoric M, Zelnickova L, Svobodova Z, Bedanova I. 2012.The effects of subchronic exposure to terbuthylazine on zebrafish. Neuroendocrinol Lett 33(Supp1 3): 113-19.

[55] Prado R, Rioboo C, Herrero C, Cid A. 2009. The herbicide paraquat induces alterations in the elemental and 
biochemical composition of non target microalgal species. Chemosphere. 76(10): 1440-4.

[56] Santos KC, Martínez CBR. 2014. Genotoxic and biochemical effects of atrazine and Roundups, alone and in combination, on the Asian clam Corbicula fluminea. Ecotoxicol. Environ. Saf. 100: 7-14.

[57] Sass JB, Colangelo A.2006. European Union Bans Atrazine, while the United States negotiates continued use. Int J Occup Env Heal 12: 260-7.

[58] Vats S. 2015. Herbicides: History, Classification and Genetic Manipulation of Plants for Herbicide Resistance Springer International Publishing Switzerland E. Lichtfouse (ed.), Sustainable Agriculture Reviews 15: 153-92

[59] Sharma P et al. 2012. Reactive oxy gen species, oxidative damage, and antioxidative defense mechanism in plants under stressful conditions. J Bot. 1-26.

[60] Shirisha K and Mastan M. 2013. Effect of antioxidant status on liver following atrazine exposure and its protection by Andrographis paniculata. IOSR J Pharm Biol Sci 7: 36- 41.

[61] Singh M, Sandhir R, Kiran R. 2010. Oxidative stress induced by atrazine in rat erythrocytes:mitigating effect of vitamin E. Toxicol Mech Method 20: 119-26.

[62] Singh M, Sandhir R, Kiran R. 2011. Effects on antioxidant status of liver following atrazine exposure and its attenuation by vitamin E. Exp Toxicol Pathol 63: 269-76.

[63] Stipicevic S, Mendas G, Dvorscak M, Fingler S, Galzina N, Baric K. 2017. Dissipation dynamics of terbuthylazine in soil during the maize growing season. Arh Hig Rada Toksikol 68: 336-42.

[64] Suwalsky M, Benites M, Villena F, Aguilar F., Sotomay or CP. 1996. Interaction of 2,4 dichlorophenoxyacetic acid (2,4-D) with cell and model membranes. Bioch. Biophys. Acta 1285: 267.

[65] Tanja Z S, Suzana Z, and Alica P. 2018. Oxidative stress in triazine pesticide toxicity: a review of the main biomarker findings Arh Hig Rada Toksikol 69: 109-125.

[66] Tetiana M. Atamaniuk, Olga I. Kubrak, Kenneth B. Storey, Volodymyr I. Lushchak. 2013. Oxidative stress as a mechanism for toxicity of 2,4-D Ecotoxicology 22: 14981508 .

[67] Torres C, Ribas G, Xamena N, Creus A, Marcos R.1992. Genotoxicity of four herbicides in the Drosophila wing spot test. Mutat Res 280: 291-95.
[68] Varona M, Henao GL, Diaz S, Lancheros A, Murcia A, Rodriguez N, Alvarez VH. 2009. Effects of aerial applications of the herbicide gly phosate and insecticides on human health. Biomedica. 29(3): 456-75.

[69] Velisek J, Stara A, Zuskova E. 2016. Effect of single and combination of three triazine metabolites at environmental concentrations on early life stages of common carp (Cyprinus carpio L.). Environ Sci Pollut R 23: 24289-97.

[70] Wang W N et al. 2012. Evaluating regional mean optima nitrogen rates in combination with indigenous nitrogen supply for rice production. Field Crops Res. 137: 37-48.

[71] WenJun Zhang 2018. Global pesticide use: Profile, trend, cost / benefit and more Proceedings of the International Academy of Ecology and Environmental Sciences. 8(1): 127.

[72] Wetzel LT, Luempert LG, Breckenridge CB, Tisdel MO, Stevens JT, Thakur AK, Extrom PJ, Eldridge JC. 1994. Chronic effects of atrazine on estrus and mammary tumor formation in female Sprague-Dawley and Fischer 344 rats. J Toxicol Env Health 43: 169-82.

[73] Williams JR. 2016. Biomarkers of oxidative stress in atrazinetreated honeybees: a laboratory and in-hive study. (Dissertation). Blacksburg: Faculty of the Virginia Poly technic Institute and State University .

[74] World Health Organization (WHO) 2018. Terbuthylazine in drinking-water. Background document for preparation of WHO Guidelines for drinking-water quality [displayed 4July 2018].

[75] Xing H, Li S, Wang Z, Gao X, Xu S, Wang X. 2012. Oxidative stress response and histopathological changes due to atrazine and chlorpy rifos exposure in common carp. Pestic Biochem Phys 103: 74-80.

[76] Zhang J, Shen H, Wang X, Wu J, Xue Y. Zhang D, Wu Y, Yuan Y, Liu W, Kuang H, Yang J, Yang B, Wu L, Zou W and $\mathrm{Xu}$ C. 2017. Exposure to 2,4-dichlorophenoxyacetic acid induces oxidative stress and apoptosis in mouse testis. Pestic Biochem Physiol. 141: 18-22.

[77] 2004 Effects of chronic exposure of 2,4-dichlorophenol on the antioxidant system in liver of freshwater fish Carassius auratus. Chemosphere 55(2): 167-174.

[78] Zhu LS, Shao B, Song Y, Xie H, Wang J, Wang JH, Liu W, Hou XX. 2010. DNA damage and effects on antioxidative enzymes in zebra fish (Danio rerio) induced by atrazine. Toxicol Mech Method 21:31-6. 
Table 1: Herbicide chemical family which directly produce ROS upon action and which produce ROS as a secondary effect.

(Herbicide Resistance Action Committee, Jan 2019)

\begin{tabular}{|l|l|}
\hline Direct ROS production & ROS- secondary effect \\
\hline Triazines, & Imidazolinone \\
Triazinones & Sulfonylurea \\
Uracils, Ureas & Sulfonamides \\
Nitriles & Sulfonylaminocarbonyl- \\
Benzothiadiazoles & triazolinones \\
Phenyl- pyridazines & Glycines \\
Diphenyl ethers & Phenoxy \\
Phenylpyrazoles & Benzoic acid \\
N-phenyl-phthalimides & Carboxylic acid \\
Oxadiazoles & Phthalamates \\
Thiadiazoles & Semicarbazones \\
Triazolinones & \\
Pyrimidinediones & \\
Bipyridylium & \\
Isoxazolidinones & \\
Pyridazinones & \\
Pyridinecarboxamides & \\
Isoxazoles & \\
Triketones & \\
Pyrazoles & \\
Phosphinic acid & \\
\hline
\end{tabular}

Table 2: Effect of different herbicides on Antioxidant parameters in various experimental models.

\begin{tabular}{|c|c|c|c|c|}
\hline Herbicide & $\begin{array}{l}\text { Experimental } \\
\text { model }\end{array}$ & $\begin{array}{lll}\text { Exposure time } & \& \\
\text { dose } & & \\
\end{array}$ & Antioxidant levels & Reference \\
\hline Terbuthylazine & Zebra fish & 28days, $>400 \mu \mathrm{g} / \mathrm{L}$ & $\begin{array}{l}\downarrow \text { TBARS }(1000 \mu \mathrm{g} / \mathrm{L}) \\
\downarrow \text { GR }(700,1000 \mu \mathrm{g} / \mathrm{L}) \\
\uparrow \mathrm{GST}(400,700 \& \\
1000 \mu \mathrm{g} / \mathrm{L})\end{array}$ & Plhalova et al. 2012 \\
\hline $\begin{array}{l}\text { Terbuthylazine } \\
\text {-2- hydroxy }\end{array}$ & $\begin{array}{l}\text { Marbeled cray fish } \\
\text { eggs }\end{array}$ & $\begin{array}{l}62 \text { days, } \\
(0.75-750 \mu \mathrm{g} / \mathrm{L})\end{array}$ & $\begin{array}{l}\downarrow \text { SOD }(375,750 \mu \mathrm{g} / \mathrm{L}) \\
\downarrow \text { TBARS }(375,750 \mu \mathrm{g} / \mathrm{L}) \\
\cdot \mathrm{CAT} \\
\cdot \mathrm{GR}\end{array}$ & Koutnik et al. 2017 \\
\hline $\begin{array}{l}\text { Terbuthylazine- } \\
\text { desethyl }\end{array}$ & Fish-common carp & $\begin{array}{l}36 \text { days, } \\
(1.80 \mu \mathrm{g} / \mathrm{L})\end{array}$ & $\begin{array}{l}\text { CAT } \\
\cdot \text { GSH } \\
\downarrow \text { GR } \\
\downarrow \text { SOD } \\
\cdot \text { TBARS }\end{array}$ & Velisek et al. 2016 \\
\hline Terbuthylazine & Rat & $\begin{array}{l}28 \text { days, } \\
(0.004,0.4 \\
\& 2.9 \mathrm{mg} / \mathrm{kg})\end{array}$ & $\begin{array}{l}\downarrow \text { Plasma SOD (0.004 \&0.4 } \\
\mathrm{mg} / \mathrm{kg}) \\
\downarrow \text { Plasma CAT }(2.9 \mathrm{mg} / \mathrm{kg}) \\
\uparrow \text { Erythrocyte SOD }(2.9 \mathrm{mg} / \mathrm{kg}) \\
\uparrow \mathrm{GPx}(0.4 \mathrm{mg} / \mathrm{kg})\end{array}$ & $\begin{array}{llll}\begin{array}{l}\text { Kisby } \\
2009\end{array} & & & \end{array}$ \\
\hline Paraquat & $\begin{array}{l}\text { Drosophilla } \\
\text { melanogaster }\end{array}$ & $\begin{array}{l}12 \mathrm{~h}, \\
(0.25 \mu \mathrm{M}-25 \mathrm{mM})\end{array}$ & $\begin{array}{l}\uparrow \mathrm{SOD} \\
\uparrow \mathrm{CAT}\end{array}$ & $\begin{array}{llll}\begin{array}{l}\text { Krucek } \\
2015\end{array} & \text { T } & \text { et } & \text { al. } \\
\end{array}$ \\
\hline Atrazine & Honey bees \& hives & $\begin{array}{l}\text { 24h,(0.1-10 } \mu \mathrm{g} / \mathrm{L}) \\
28 \text { days }(10 \mu \mathrm{g} / \mathrm{L})\end{array}$ & $\begin{array}{l}\downarrow \text { GPX } \\
\downarrow \text { GST } \\
\uparrow \mathrm{MDA}\end{array}$ & Willims JR 2016 \\
\hline
\end{tabular}




\begin{tabular}{|c|c|c|c|c|}
\hline Atrazine & Rat Blood \&liver & $300 \mathrm{mg} / \mathrm{kg}$ & $\begin{array}{l}\uparrow \mathrm{CAT} \\
\uparrow \mathrm{SOD} \\
\uparrow \mathrm{GPx} \\
\uparrow \mathrm{GST} \\
\downarrow \mathrm{GSH}\end{array}$ & $\begin{array}{l}\text { Singh et al. } 2010 \& \\
\text { Shrisha K and } \\
\text { Mastan M. } 2013\end{array}$ \\
\hline Atrazine & Rat testis & $25-200 \mathrm{mg} / \mathrm{kg}$ & $\downarrow \mathrm{CAT}$ & $\begin{array}{l}\text { Abarikwu SO et } \\
\text { al. } 2010\end{array}$ \\
\hline $\begin{array}{l}\text { Acetachlor/ } \\
\text { Metachlor }\end{array}$ & $\begin{array}{ll}\text { Soil } & \text { Bacterial } \\
\text { isolates } & \end{array}$ & $\begin{array}{l}62 \& 620 \mathrm{mM} / \\
34 \& 340 \mathrm{mM} \\
(24 \mathrm{~h}) \\
\end{array}$ & $\begin{array}{l}\text { 个CAT } \\
\uparrow \mathrm{MDA}\end{array}$ & $\begin{array}{l}\text { P.F. Martins et al. } \\
2011\end{array}$ \\
\hline $2,4-\mathrm{D}$ & Mouse testis & $\begin{array}{l}14 \text { days, } \\
(100,200 \mathrm{mg} / \mathrm{kg})\end{array}$ & $\begin{array}{l}\uparrow \mathrm{MDA} \\
\downarrow \mathrm{SOD} \\
\downarrow \mathrm{CAT} \\
\end{array}$ & $\begin{array}{llll}\text { Zhang } & \text { D } & \text { et } & \text { al. } \\
2017 & & & \end{array}$ \\
\hline $2,4-\mathrm{D}$ & $\begin{array}{l}\text { Umbelopsis } \\
\text { is abelina (fungus) }\end{array}$ & $24 \mathrm{~h}, 120 \mathrm{~h}(100 \mathrm{mg} / \mathrm{L})$ & $\begin{array}{l}\downarrow \mathrm{CAT} \quad 24 \mathrm{~h} \quad(34.43 \%), \quad 120 \mathrm{~h} \\
(21.8 \%) \\
\uparrow \mathrm{TBARS}(38 \%)\end{array}$ & Bernat $p$ et al. 2018 \\
\hline $2,4-\mathrm{D}$ & Gold fish liver & 40 days & $\begin{array}{l}\uparrow \mathrm{GSSG} \\
\downarrow \mathrm{GSH}\end{array}$ & Zhang et al. 2004 \\
\hline $2,4-\mathrm{D}$ & Gold Fish gills & $96 \mathrm{~h},(1,10,100 \mathrm{mg} / \mathrm{L})$ & $\begin{array}{l}\uparrow \mathrm{MDA} \\
\uparrow \mathrm{SOD} \quad(29 \quad \& \quad 35 \% \text { at } 10 \& \\
100 \mathrm{mg} / \mathrm{L}) \\
\uparrow \mathrm{CAT}(41 \% \text { at } 100 \mathrm{mg} / \mathrm{L}) \\
\uparrow \mathrm{GPx}(19-33 \%) \\
\uparrow \mathrm{GSSG}(49 \% \text { at } 100 \mathrm{mg} / \mathrm{L}) \\
\downarrow \mathrm{GSH}(20 \% \text { at } 100 \mathrm{mg} / \mathrm{L})\end{array}$ & $\begin{array}{l}\text { T. M. Atamaniuk et } \\
\text { al. } 2013\end{array}$ \\
\hline
\end{tabular}

